"Market orientation and performance: the contingency role of external environment"

AUTHORS Brownhilder Ngek Neneh

ARTICLE INFO

Brownhilder Ngek Neneh (2016). Market orientation and performance: the contingency role of external environment. Environmental Economics, 7(2), 130137. doi:10.21511/ee.07(2).2016.14

DOI http://dx.doi.org/10.21511/ee.07(2).2016.14

RELEASED ON Friday, 03 June 2016

JOURNAL "Environmental Economics"

FOUNDER LLC "Consulting Publishing Company "Business Perspectives"

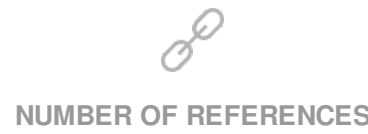

0

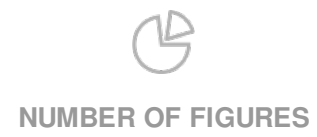

0

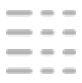

NUMBER OF TABLES

0

(C) The author(s) 2022. This publication is an open access article. 
Brownhilder Ngek Neneh (South Africa)

\title{
Market orientation and performance: the contingency role of exter- nal environment
}

\begin{abstract}
In today's business environment characterized by intense competition from globalization and incessantly changing customer needs, market orientation (MO) has been presented as a valuable approach for firms to safeguard themselves against market fluctuations and maintain continuous superior performance. Even though existing literature suggest that MO is a vital driver of business performance, some studies have failed to find its benefits. This is possibly because the MO-performance relationship is has been argued to be context specific and contingent to the business environment. This study thus had as objective to investigate the impact of MO on SME performance, as well as the moderating effects of the external environment on the MO- performance nexus. Using data from South Africa, this study showed that two of the three dimensions of MO (i.e. customer orientation, competitor focus) are significant drivers of business performance and that the MO-performance nexus is moderated by the external environmental factors. Specifically the MO-performance relationship is positively moderated by market turbulence and negative moderated by technological turbulence and competitive intensity. The study culminates with theoretical and practical implications that can be valuable for scholars and businesses operating in South Africa.
\end{abstract}

Keywords: market orientation, customer orientation, competitor focus, interfunctional coordination, environmental factors, firm performance.

JEL Classification: M13, M21, M51, L25.

\section{Introduction}

In a dynamic market place characterized by changing customer needs and preferences, rapid technological advances and a multifaceted competitive landscape, the concept of market orientation (MO) has been used to explain why some firms achieve greater performance than their competitors (Njeru \& Munyoki, 2014). MO is defined as an organizational level culture consisting of the values and belief about putting the customer first in their business planning (Jones, Wheeler \& Dimitratos, 2011). MO is also described as a form of organizational culture whereby the workers within an organization are systematically and fully dedicated to the continuous creation of superior customer value (Narver \& Slater, 1990; Kohli \& Jaworski, 1990).

For a long time $\mathrm{MO}$ has been regarded as an important capability of a firm. As such, MO has been identified and acknowledged as a source of competitive advantage and can be an important determinant of firm performance (Njeru \& Munyoki, 2014). Prior studies (Gudlaugsson \& Schalk, 2009; Reijonen, Laukkanen, Komppula \& Tuominen, 2012) have established that businesses which are market-orientated tend to be efficient and perform much better than those that are less marketorientated. This is because they are able to satisfy customers through tracking and responding to customer needs and preferences (Jaworski and

\footnotetext{
(c) Brownhilder Ngek Neneh, 2016.

Brownhilder Ngek Neneh, Dr., Senior Lecturer, Department of Business Management, University of the Free State, South Africa.
}

Kohli, 1993). Hong, Song and Yoo (2013) found MO to be a necessary prerequisite for strong market performance and is also crucial in strengthening the firms' innovation. $\mathrm{MO}$ gives small businesses a potential competitive advantage over their larger counterparts, as they are closer to their customers and can respond quickly and flexibly to their needs (Reijonen et al., 2012). Likewise, Ong, Yeap and Ismail (2015) explicated that SMEs use MO as an important firm capability to build competencies that otherwise required heavy financial investments which they cannot afford. Hence, adopting a market-orientated strategy is posited as a way of enhancing the performance of small businesses.

Nonetheless, the external environment in which businesses operate is complex and constantly changing and as such, in order for businesses to respond to the constantly changing business environment, they must adapt to their surroundings by being flexible and quick, if they in turn to survive and prosper (AL-Shubiri, 2012). External environmental factors are capable of determining the failure and success of the firms. Researchers (Narver and Slater, 1990; Gima, 1995) advocate that the importance of MO for organizational performance depend on environmental condition. This is because a strong $\mathrm{MO}$ is required to enable businesses concentrate on those environmental events that are likely to influence their ability to enhance customer satisfaction relative to competitors (Erdil, Erdil \& Keskin, 2010). Consequently, it is imperative that businesses monitor their external environment when considering the development of a strong market-oriented culture (Kohli \& Jaworski, 1990). 
A plethora of evidence on the MO construct and MO-performance relations abound. Whileseveral researchers have established a strong positive association between $\mathrm{MO}$ and performance (Gaur, Vasudevan \& Gaur, 2011; Hau, Evangelista \& Thuy, 2013), others have found no significant direct effect or weak relationship (Sargeant \& Mohamad, 1999; Nwokah, 2008; Harris, 2001). Diamantopoulos and Hart (1993) pointed out that the MO-performance nexus is situation specific and also subject to several moderating influences. Slater and Narver (1994) and Kohli and Jaworski (1990) expound that the business environment might affect the MO-performance relationship. Prior studies (Kohli \& Jaworski, 1990; Narver \& Slater, 1990; Van Raaij \& Stoelhorst, 2008; Njeru \& Munyoki, 2014) have extensively studied MO under various moderating influences of environmental factors such as market turbulence, competitive intensity, and technological turbulence. Some of the environmental factors that have been shown to moderate the EO-performance relationship include market turbulence (Pulendran, Speed \& Widing, 2000), technological turbulence (Rose \& Shoham, 2002) and competitive intensity (Grewal \& Tansujah, 2001). However, other researchers found no support for the moderating role of these environmental factors on the EO-performance relationship (Morah, Wilson \& Tzempelikos, 2015; Kirca, Jayachandran \& Bearden, 2005; Aziz \& Yassin, 2010). The disparity across these findings could be as a result of the culture, industries, structures, size of firms as well as the differences in the stages of economic development amongst the countries studied (Appiah-Adu 1998; Ellis, 2006). These conflicting findings to date have not been widely tested at empirical level to a very large extent by prior studies in South Africa, which underpin this present study. As such the need and importance to research on how SMEs can better able to satisfy their customers' needs and strive to keep ahead of their competitors. Consequently, this study has as objectives to investigate the impact of MO on SME performance, as well as the moderating effects of the external environment on the MO-performance nexus.

\section{Literature review}

\section{Market orientation}

Researchers (Kohli \& Jaworski, 1990; Narver \& Slatter, 1990; Carr \& Lopez, 2007) have pointed out that MO traces its origin from the marketing concept and thus has great significance to the overall business strategy. The marketing concept implies that through timely identification and satisfaction of the consumers' needs, the long term benefits can be attained. Two different widely used classifications of MO have emerged over the years, namely: the cultural perspective by Narver and Slater (1990) and the behavioral perspective by Kohli and Jaworski (1990). This paper acknowledges that while both perspectives are critical to firm performance, nonetheless, this study focuses on cultural perspective. This is because the cultural perspective outperforms the behavioral perspective in explaining business performance variance and also has a stronger association with business performance as its central focus is on providing customer value and superior business performance (Narver \& Slater, 1990; Oczkowski \& Farrell, 1998; Vieira, 2010). Narver and Slater (1990, p. 21) define market orientation as "the organizational culture that most effectively and efficiently creates the necessary behaviors for the creation of superior value for buyers and thus continuous superior performance for the business". These authors pointed out that MO comprises of three cultural components (i.e. customer orientation, competitor focus and inter-functional coordination) and two decision criteria (i.e., long-term focus and profit objectives).

Customer orientation is defined by Day (1994) as "a concept which transforms marketing into a potent competitive weapon, shifting organizational values, beliefs, assumptions, and premises towards a twoway relationship between customers and the firm". Customer orientation necessitates that sellers understand the value chain of buyers so as to create superior value for them on a continuous basis (Narver \& Slater, 1990). Studies by Asomaning and Abdulai (2015) pointed out that customer orientation has a strong positive and significant association with the market performance of small businesses in Ghana. Also, Asikhia (2010) in his study on SMEs in Nigeria established a positive relationship between customer orientation and firm performance. Additionally, Dauda and Akingbade (2010) established a positive relationship between customer orientation and performance of Small Business Enterprises in Nigeria. Likewise, Pongwiritthon and Awirothananon (2014) also established a positive and significant relationship between customer orientation and firm performance among SME in Thai. Hence, in order for businesses to be customer oriented, they need to get information about their customers, engage in excellent customer interactions, market and customer familiarity and also place emphasis on cooperation.

Competitor orientation means the sellers have an understanding of the short term strengths and weaknesses and long-term capabilities and strategies of both its current and future competitors (Narver \& Slater, 1990; Asomaning \& Abdulai, 2015). Thus, this acts as a basis for creating value, customer loyalty and increased profitability.Dauda andAking- 
bade (2010) established a positive relationship between competitor orientation and firm performance of Small Business Enterprises in Nigeria. Also, Narver and Slater (1996) in their study observed that competitor orientation has a positive influence on firm performance. Likewise, Asomaning \& Abdulai (2015) in their study on small businesses in Ghana found a strong positive and significant relationship between competitor orientation and market performance.

Inter-functional coordination shows how a business utilises its resources to create superior value for its target customers (Narver \& Slater, 1990; Asomaning \& Abdulai, 2015). Inter-functional coordination facilitates the communication between functional areas that help in the formation of market conditions that successfully create superior value for customers and serve both internal and external customers.Lin (2007) established a positive association between inter-functional coordination and small business financial performance in Australia, while Asomaning \& Abdulai (2015) also found a strong positive and significant relationship between inter-functional coordination and market performance of small businesses in Ghana.

\section{The external environment as a moderating factor}

Environmental variables have always been acknowledged as critical contingency factors in the MO-performance relationship (Kohli \& Jaworski, 1990; Slater \& Narver, 1994). Prior studies (Kohli \& Jaworski, 1990; Kumar, Jones, Venkatesan \& Leone, 2011; Narver \& Slater, 1990; Njeru \& Munyoki, 2014; Van Raaij \& Stoelhorst, 2008) have extensively studied MO under various moderating influences of environmental factors such as market turbulence, competitive intensity, and technological turbulence. Market turbulence is defined as the changes in the composition of customer's taste and preferences (Zairi, 2011). Kohli and Jaworski (1993) pointed out that the greater the market turbulence, the stronger the MO-performance nexus. These researchers affirm that a higher level of MO is most likely to have a little effect on performance in a stable market with a fixed set of customers and stable preferences. This is because little adjustment to the marketing mix is needed. On the other hand, businesses operating in a more turbulent market are most likely to have a greater need for $\mathrm{MO}$ as it will be easy for them to track and respond to changing customer preferences.Nonetheless, studies by (Slater\& Narver, 1994; Kirca, Jayachandran \& Bearden, 2005; Morah, Wilson \& Tzempelikos, 2015) failed to find any moderating role of market turbulence on the MO-performance relationship.
Technology turbulence was introduced by Kohli and Jaworski (1990) as another moderator in the MOperformance nexus. They defined technology as the "entire process of transforming input to output and the delivery of those outputs to end-user" and thus consider technology turbulence as the prevalence of changes in the entire industry's technology. These researchers asserted that the greater the technology turbulence, the weaker the relationship between MO and business performance. Later studies by Jaworski and Kohli (1993) supported this assertion by explicating that while $\mathrm{MO}$ is a stronger determinant of business performance in industries with low technology turbulence, $\mathrm{MO}$ is a less important determining factor of business performance in industries with high technology turbulence when compared to industries in technologically stable environments (Zairi, 2011). This is because in a technologically turbulence environment, businesses can get a superior competitive advantage by capitalising on their superior $\mathrm{R} \& \mathrm{D}$ capabilities, which will in turn offer them a superior ability to deal with fast changing technological environment. On the other hand, businesses operating in industries with a stable technology will not be able to get any benefits by relying on technology for competitive advantage. Morah et al. (2015) established that technological turbulence negatively moderates the MO-performance relationship amongst businesses in Nigeria. However, Kirca et al. (2005) did not find any empirical support for the moderating roles of technology turbulence on the MO-performance relationship.

With regards to competitive intensity, Kohli and Jaworski (1990) established that the greater the competition, the stronger the MO-performance relationship. This is because a business is more likely to survive in an industry environment with high levels of competitive intensity as opposed to les competitive industry environment(Zairi, 2011). Businesses that are market oriented turn to focus on understanding the needs and wants of their customers, monitor competitors activities, understand competitive strategies and respond to them and thus more likely to attract and retain more customers. On the other hand, with high levels of competitive intensity, businesses that are not market oriented turn to lose customers to competitors (Kohliand Jaworski, 1990). Morah et al. (2015) found that competitive intensity plays a positive moderating role in the MOprofitability relationship. Hence, higher level of competitive intensity increases $\mathrm{MO}$ as a source of competitive advantage, as businesses that are market oriented perform better. Nonetheless, a metaanalytical review by Kirca et al. (2005) fails to find empirical support for the moderating roles of competitive intensity on the MO-performance relationship. 


\section{Methodology}

\section{Sample and data collection}

Data was collected by means of self-administered questionnaires. The sample comprized of entrepreneurs in the Mangaung metropolitan municipality in the Free State province of South Africa. Given the lack of database of entrepreneurs in the Free State and South Africa in general, the convenience sampling method was adopted for this study and supplemented with snowball sampling. The Yellow pages directory was used to identify potential respondents, after which, the researcher visited them at their specific business locations. A total of 450 questionnaires were administered to the entrepreneurs, of which 320 were fully completed and returned resulting in a valid response rate of $71.1 \%$.

\section{Variables and measures}

\section{Market orientation}

MO has been measured using different variables by many researchers. In this study, MO is measured using the MKTOR scales as used by prior studies (Narver and Slater's, 1990; Morah et al, 2015; Asomaning \& Abdulai, 2015; Dauda and Akingbade, 2010). The MKTOR scale is a 15-item scale, and the three components it measures are customer orientation (6 items); competitor orientation (4 items) and interfunctional coordination ( 5 items). The responses were captured on a 5 point Likert-type scale ranging from strongly disagree (1) to strongly agree (5) as used in prior studies (Narver and Slater, 1990; Dauda and Akingbade, 2010).

\section{Control variables}

This study adopted the firm's age as a control variable. The firm's age has been identified as an important factor that affects a firm's performance. This is because a firm's age indicates the power and experience a firm has in a particular industry, which can thus be influential to the firm's performance (Inmyxai \& Takahashi, 2010). Also, Watson (2002) pointed out that while younger firms turn to have lower sales which in turn leads to lower profits, older firms on the other hand turn to be larger in terms of sales turnover, capital assets and number of employees.

\section{External environment}

The three external environmental moderators (market turbulence, competitive intensity, and technological turbulence) were measured using Jaworski and Kohli's (1993) scale as used in prior studies (e.g. Morah et al., 2015; Jaworski \& Kohli, 1993). Market turbulence, competitive intensity, and technolo- gical turbulence were measured by three scales comprising of six, six and five items, respectively.

\section{Firm performance}

In this study, a subjective measure was adopted for measuring firm performance as used in prior studies (Keh, Nguyen \& Ng (2007; Wiklund \& Shepherd, 2005; Jaworski \& Kohli, 1993). Firm performance was measured as a cumulative aspect of three different items (growth in the number of employees, growth of market share and sales growth), where respondents were asked to assess the overall performance of their businesses relative their competitors, rated on a 5 point Likert-type scale ranging (1) from much poor than competitors, to (5) much better than competitors.

\section{Results}

\section{Profile of respondents}

450 questionnaires were distributed to SME ownermanagers of which 320 were fully completed and returned resulting in a response rate of $71.1 \%$. The majority of respondents were males (51.6\%) as opposed to females (48.4\%). Also, the majority of the respondent $(76 \%)$ came from entrepreneurial families. Moreover, less than $50 \%$ of the SME owner-managers had highest qualification as matric. In addition, the Cronbach's alpha was to determine the internal consistency of the variables for $\mathrm{MO}$ and external environment. The alpha values of 0.82 , $0.902,0.912,0.707,0.708$ and 0.806 were obtained for customer orientation, competitor orientation, Interfunctional coordination, market turbulence, technology and competitive intensity respectively. Thus, there is high internal consistency rate (alpha $>$ 0.7 ) and validated the use of these measures for the analyses performed below.

Table 1. Results on the MO dimensions construct and firm performance

\begin{tabular}{|l|c|c|}
\hline \multirow{2}{*}{ Factors } & \multicolumn{2}{c|}{ Model 1 } \\
\cline { 2 - 3 } & Beta & $T$-value \\
\hline Constant & & $4.940^{* *}$ \\
\hline Log (age) & 0.444 & $8.607^{* *}$ \\
\hline Customer orientation (CUO) & 0.170 & $2.485^{\star}$ \\
\hline Competitor orientation (COO) & 0.217 & $3.148^{* *}$ \\
\hline Interfunctional coordination (IC) & 0.066 & 1.265 \\
\hline Model parameters & \multicolumn{2}{|c|}{0.202} \\
\hline$R^{2}$ & \multicolumn{2}{|c|}{0.191} \\
\hline Adjusted $R^{2}$ & \multicolumn{2}{|c|}{$19.873(0.00)^{\star \star}$} \\
\hline$F$-value (sig.) & \multicolumn{2}{|c|}{0.188} \\
\hline$R^{2}$-change & \multicolumn{2}{|c|}{$74.081(0.00)^{\star *}$} \\
\hline$F$-change & \multicolumn{2}{|c}{} \\
\hline
\end{tabular}

Notes: $* *$ Sig at $1 \%, *$ Sig at $5 \%$. 
The results on Table 1 show the regression analysis for each of the dimensions of MO and SME performance, while including firm's age as a control variable. The results indicate that for the EO constructs, only interfunctional coordination does not have a significantrelationship with firm performance. Customer orientation and competitor orientation have a significant positive influence on firm performance and the results are significant at the $5 \%$ and $1 \%$ level respectively. The findings are congruent with prior studies (Pongwiritthon \& Awirothananon, 2014; Asomaning \& Abdulai, 2015; Asikhia, 2010) that found a positive and significant relationship between customer orientation and firm performance. Similarly, the results are in accordance with the numerous studies (Narver \& Slater, 1990; Asomaning \& Abdulai, 2015; Dauda \& Akingbade, 2010) that have established a strong positive and significant relationship between competitor orientation and firm performance. Interfunctional coordination has apositive relationship with firm performance, though the results are not statistically significant. This result is contrary to the findings of (Lin, 2007; Asomaning \& Abdulai, 2015) which found a significant positive relationship between interfunctional coordination and firm performance.

Table 2. Moderating effect of external environment on MO-performance relationship

\begin{tabular}{|c|c|c|c|c|c|c|c|c|}
\hline \multirow{2}{*}{ Factors } & \multicolumn{2}{|c|}{ Model 1} & \multicolumn{2}{|c|}{ Model 2} & \multicolumn{2}{|c|}{ Model 3} & \multicolumn{2}{|c|}{ Model 4} \\
\hline & Beta & T-Value & Beta & T-value & Beta & T-value & Beta & T-value \\
\hline \multicolumn{9}{|l|}{ Control variables } \\
\hline Constant & & $10.624^{* *}$ & & $5.173^{\star \star}$ & & $4.617^{\star \star}$ & & $4.611^{\star *}$ \\
\hline Log (age) & 0.416 & $8.166^{* *}$ & 0.423 & $8.307^{\star *}$ & 0.451 & $8.215^{\star \star}$ & 0.468 & $8.773^{\star *}$ \\
\hline \multicolumn{9}{|c|}{ Independent variables } \\
\hline Market orientation & & & 0.092 & 1.807 & 0.236 & $3.914^{\star *}$ & 0.210 & $3.530^{* *}$ \\
\hline \multicolumn{9}{|c|}{ Moderating variables } \\
\hline Market turbulence (MT) & & & & & -0.096 & -1.306 & -0.155 & $-2.152^{*}$ \\
\hline Technology turbulence (TT) & & & & & -0.295 & $-4.458^{* *}$ & -0.148 & $-2.114^{*}$ \\
\hline Competitive intensity (Cl) & & & & & 0.085 & 1.301 & 0.050 & 0.766 \\
\hline \multicolumn{9}{|c|}{ Interaction items } \\
\hline $\mathrm{MO} \times \mathrm{MT}$ & & & & & & & 0.157 & $2.244^{*}$ \\
\hline MO x TT & & & & & & & -0.256 & $-4.130^{\star *}$ \\
\hline $\mathrm{MO} \times \mathrm{Cl}$ & & & & & & & -0.250 & $-3.895^{\star \star}$ \\
\hline \multicolumn{9}{|l|}{ Model parameters } \\
\hline $\mathrm{R}^{2}$ & \multicolumn{2}{|c|}{0.173} & \multicolumn{2}{|c|}{0.182} & \multicolumn{2}{|c|}{0.275} & \multicolumn{2}{|c|}{0.349} \\
\hline Adjusted R² & \multicolumn{2}{|c|}{0.171} & \multicolumn{2}{|c|}{0.177} & \multicolumn{2}{|c|}{0.264} & \multicolumn{2}{|c|}{0.332} \\
\hline F-value (sig.) & \multicolumn{2}{|c|}{$66.691(0.00)^{\star \star}$} & \multicolumn{2}{|c|}{$35.215(0.00)^{* *}$} & \multicolumn{2}{|c|}{$23.874(0.00)^{* *}$} & \multicolumn{2}{|c|}{$20.828(0.00)^{* *}$} \\
\hline $\mathrm{R}^{2}$-change & \multicolumn{2}{|c|}{-} & \multicolumn{2}{|c|}{0.008} & \multicolumn{2}{|c|}{0.094} & \multicolumn{2}{|c|}{0.073} \\
\hline F-change & \multicolumn{2}{|c|}{ - } & \multicolumn{2}{|c|}{$3.264(0.72)$} & \multicolumn{2}{|c|}{$13.592(0.00)^{\star \star}$} & \multicolumn{2}{|c|}{$11.688(0.00)^{\star \star}$} \\
\hline
\end{tabular}

Notes: ** Sig at $1 \%, *$ Sig at $5 \%$.

The results on Table 2 show the moderating effect of the external environment (market turbulence, technology turbulence and competitive intensity) on the MO-performance relationship. Model 1 included only the firm's age as the control variable and the result show that $F$-value is significant $(p \leq 0.05)$ indicating the overall significance of the model.

In Model 2, the independent variable (market orientation) was included in the model. The probability of the $F$-value is significant at the $1 \%$ level, which is an indication that the overall model is significant and thus valuable in predicting firm performance. The results depict that market orientation has a positive relationship with firm performance, though the results are not statistically significant.This is in line with studies (Nwokah, 2008; Harris, 2001) who also observed no significant relationship between market orientation and firm performance.
In Model 3, the moderating factors (market turbulence, technology turbulence and competitive intensity) were added to model 2 . The results show that the probability of the F-value is significant at the $1 \%$ level, illustrating the overall significance of the model. The addition of the moderating factors (market turbulence, technology turbulence and competitive intensity) to the model meaningfully affected the model as the prediction power of the model significantly increase $\left(R^{2}\right.$-change $=9.4 \% ; F$ Change $=13.592 ; p<0.05)$. The results indicate that technology turbulence has a negative relationship with firm performance and the results are statistically significant at the $1 \%$ level. Also, the relationship between market turbulence and firm performance was negative, while the relationship between competitive intensity and firm performance is positive, albeit the results are not statistically significant. Interestingly, with the addition of environ- 
mental factors, the impact of $\mathrm{MO}$ on performance which was not previously significant in model 2 becomes significant. The affirms the previously expressed views that acknowledges environmental factors as critical contingency factors for MOperformance relationship (Kohli \& Jaworski, 1990; Slater \& Narver, 1994; Njeru \& Munyoki, 2014; Van Raaij \& Stoelhorst, 2008).

In Model 4, the interaction item (MO x MT; MO x TT; MO $\mathrm{x} \mathrm{CI}$ ) were included in the model. The probability of the $F$-value showed that the overall model is significant $(F=11.688 ; p<0.05)$ thus depicting the overall model as a good predictor of firm performance. Also, adding the interaction variable to the model significantly increases the predictability of the model as depicted by the significance of the $F$ change value. It is observed that the addition of interaction variables increases the variance explained by the model by $7.3 \%\left(R^{2}\right.$-Change $)$. Market turbulence showed a significant positive moderating effect on the MO-performance relationship ( $\beta=0.638$; $P<0.05$ ), while both technology turbulence and competitive intensity showed significant negative moderating effects $(\beta=-0.256 ; P<0.01 ; \beta=-0.250 ; P$ $<0.01$ respectively). Morah et al. (2015) established that technological turbulence negatively moderate the MO-profitability (objective performance measure) relationship amongst businesses in Nigeria, which confirms to the findings of this study. Also, competitive intensity positively moderates MOprofitability relationship while market turbulence does not moderate the relationship, which contradicts the findings of this study.

\section{Theoretical and managerial implications}

The fact that all three dimension of MO have a positive relationship with performance shows that MO is an important capability of a firm and thus can be used as a source of competitive advantage. This results are congruent with prior studies (Gaur, Vasudevan \& Gaur, 2011; Hau, Evangelista \& Thuy, 2013), which also found a positive association between market orientation and firm performance. A significant positive relationship with customer orientation, competitive orientation and firm performance depict that SMEs who understand the weaknesses and strength of their current and potential competitors, as well the value chain of buyer are able to create superior value to them on a continuous basis. Interfunctional coordination having a positive but statistically insignificant relationship with firm performance, indicate that given that most SMEs have very few employees and thus do not have departments, there is an effective flow of downward and upward communication amongst them.
With regards to the moderating factors, this study established that market turbulence positively moderates the MO-performance relationship which is akin to findings by Morah et al. (2015) and Kumar et al. (2011). Technology turbulence and competitive intensity negatively moderates the MOperformance relationship. This finding is in contrast with Kirca et al. (2005) who fail to find empirical support for the moderating roles of competitive intensity and technology turbulence on the MOperformance relationship. Market turbulence positively moderating the MO-performance nexus indicates that businesses operating in a more turbulence market are most likely to have a greater need for market orientation as it will be easy for them to track and respond to changing customer preferences.

Technology turbulence negatively moderating the MO-performance relationshipis in accord with the MO's empirical literature (Morah et al., 2015; Jaworski \& Kohli, 1993; Zairi, 2011). These results suggest that the performance of a firm decreases when the business is operating in an environment characterized by high technology turbulence; thus the greater the technology turbulence, the weaker the relationship between $\mathrm{MO}$ and business performance. Hence, when SMEs are operating in an environment characterized by technological turbulence, in order to cope, entrepreneurs may need to capitalize on their superior $R \& D$ capabilities, so as to get a superior competitive advantage. This view is equally shared by Ellis (2006) and Morah et al. (2015) who elucidate that the managerial value of market orientation is extensively affected by cultural and economic characteristics of the host country. Consequently, businesses operating in South Africa should operate with the knowledge that the country shares nomological differences with their home countries. In addition, continuous investments in market orientation is necessary, particularly in industries characterized as highly turbulent.

Competitive intensity negatively moderating the MO-performance mirrors the findings by Morah et al. (2015) and Kumar et al. (2011), but contradicts other prior research (Jaworski \& Kohli 1993; Slater \& Narver 1994), who found no empirical support for the moderating roles of competitive intensity on the MO-performance relationship. This result suggest that businesses in South Africa are operating in an industry environment with high levels of competitive intensity. Business that is market-oriented turn to focus on understanding the needs and wants of its customers, monitor competitors activities, understand competitive strategies and respond to them and thus more likely to attract and retain more customers. Thus, the greater the competition, the stronger MO-performance relationship. 


\section{Limitations and future research directions}

In measuring market orientation, many researchers have used different variables. In this study, market orientation is measured using the MKTOR scales. Future studies on market orientation in South Africa should incorporate other different measures of market orientation such as the MARKOR, which is a 32-item scale and measures an organization's focus on intelligence generation, intelligence dissemination, and responsiveness, to find out if there are any significant differences when it comes to explaining business performance variance.

\section{Conclusion}

In conclusion, this study has provided valuable insight as to how market orientation is an important determinant of firm performance and a source of competitive advantage for businesses. From the discussion, it is obvious that SMEs will perform well if market orientation is enhanced and practiced. SME owners/mangers need to incorporate market orientation as part of their organizational culture and philosophy since it has been found to enhance small business performance. This can be achieved if customers and their needs are prioritized, and customer information successful disseminated amongst SME owners/mangers and their employees. Yet again, SME owners/managers need to continuously scan the environment to understand the strength and weaknesses of their current and potential competitors, as well as the value chain of buyers so they can be able to create superior value to customers on a continuous basis. Furthermore, the impact of the external environmental variables as a critical contingency factor in the MO-performance relationship has been reiterated by this study and the failure to take into consideration the effect of environmental moderators in prior research in South Africa could be ascribed to the omission of lagged effects. For policy makers, the quest of finding solutions to the dismal performance of SMEs should not be limited to providing financial support, but also to ensure that they develop and provide training programs that will train and equip SMEs owners/managers with a market oriented culture and attitude.

\section{References}

1. AL-Shubiri, N.F. (2012). Measuring the Impact of Business Intelligence on Performance: An Empirical Study, Polish Journal of Management Studies, 6, pp. 1-12.

2. Appiah-Adu, K. (1998). Market orientation and performance: empirical tests in a transition economy, Journal of Strategic Marketing, 6, pp. 25-45.

3. Asikhia, A. (2010). Customer Orientation and Firm Performance among Nigerian Small and Medium Scale Businesses, International Journal of Marketing Studies, 2(1), pp. 197-212.

4. Asomaning, R. \& Abdulai, A. (2015). An Empirical Evidence of the Market Orientation - Market Performance Relationship in Ghanaian Small Businesses, Educational Research International, 4(2), pp. 69-86.

5. Aziz, N.A. \& Yassin, N.M. (2010). How Will Market Orientation and External Environment Influence the Performance among SMEs in the Agro-Food Sector in Malaysia, Journal of international Business Research, 3, pp. 154-164.

6. Dauda, A.Y. \& Akingbade, A.W. (2010). Employee's Market Orientation and Business Performance in Nigeria: Analysis of Small Business Enterprises in Lagos State, International Journal of Marketing Studies 2(2), pp. 134-143.

7. Day, G. \& Nedungadi, P. (1994). Managerial representation of competitive advantage, Journal of Marketing, 58(2), pp. 31-44.

8. Diamantopoulos, A. and Hant, S. (1993). Linking market orientation and company performance: preliminary evidence on Kohli and Jaworski's framework, Journal of Strategic Marketing, 1, pp. 93-121.

9. Ellis, P.D. (2006). Market orientation and performance: a meta-analysis and cross national comparisons, Journal of Management Studies, 43(5), pp. 1089-1097.

10. Erdil, S. \& Erdil, O. \& Keskin, H. (2010). The relationships between market orientation, firm innovativeness and innovation performance, Journal of Global Business and Technology, pp. 1-11.

11. Gaur, S.S., Vasudevan, H. and Gaur, A.S. (2011). Market orientation and manufacturing performance of Indian SMEs: moderating role of firm resources and environmental factors, European Journal of Marketing, 45(7/8), pp. 1172-1193.

12. Gima, K.A. (1995). An Exploratory Analysis of the Impact of Market Orientation on New Product Performance, Journal of Product Innovation Management, 12, pp. 275-293.

13. Grewal, R. and Tansuhaj, P. (2001). Building Organizational Capabilities for Managing Economic Crisis: The Role of Market Orientation and Strategic Flexibility, Journal of Marketing, 65(2), pp. 67-80.

14. Gudlaugsson, T. and Schalk, A.P. (2009). Effect of Market Orientation on Business Performance: Empirical Evidence from Iceland, The European Institute of Retailing and Services Studies, 6, pp. 1-17.

15. Hashim, F. \& Abu Bakar, A. 2011. Antecedents and consequences of Market Orientation in Non-Profit Organizations: Evidence From Malaysia, International Journal Of Management And Marketing Research, 4(3), pp. 95-105.

16. Hau, L.N., Evangelista, F. \& Thuy, P.N. (2013). Does it pay for firms in Asia's emerging markets to be market oriented? Evidence from Vietnam, Journal of Business Research, 66(12), pp. 2412-2417.

17. Hong, J., Song, T.H. and Yoo, S. (2013). Paths to Success: How Do Market Orientation and Entrepreneurship Orientation Produce New Product Success? Journal of Product Innovation Management, 30(2), pp. 44-55. 
18. Inmyxai, S. \& Takahashi, Y. (2010). The Effect of Firm Resources on Business Performance of Male- and FemaleHeaded Firms in the Case of LaoMSMEs, International Journal of Business and Information, 5(1), pp. 64-88.

19. Jaworski, B.J. \& A.K., Kohli. (1993). Market-Orientation: Antecedents and Consequences, Journal of Marketing, 57(3), pp. 53-70.

20. Jones, V.M., Wheeler, C. \& Dimitratos, P. (2011). International Entrepreneurship in the Life Sciences. UK: Edward, Elgar Publishing Limited.

21. Keh, H.T., Nguyen, T.T.M. \& Ng, H.P. (2007). The effects of entrepreneurial orientation and marketing information on the performance of SMEs, Journal of Business Venturing, 22(4), pp. 592-611.

22. Kirca, A., Jayachandran, S. and Bearden, W. (2005). Market Orientation: A Meta-Analytic Review and Assessment of Its Antecedents and Impact on Performance, Journal of Marketing, 69 (2), pp. 24-41.

23. Kohli, A.K. \& Jaworski, B.J. (1990). Market orientation: the constructs research propositions, and managerial implications, Journal of Marketing, 54, pp. 1-18.

24. Kumar, V., Jones, E., Venkatesan, R. \& Leone, R.P. (2011). Is market orientation a source of sustainable competitive advantage or simply the cost of competing? Journal of Marketing, 75 (January), pp. 16-30.

25. Lin, S.T.C. (2007). Sources of competitive advantage for emerging fast growth small-to-medium enterprises: the role of business orientation, marketing capabilities, customer values, and firm performance, Royal Melbourne Institute of Technology, Australia. Unpublished Thesis. From: http://adt.lib.rmit.edu.au/adt/uploads/approved/ adtVIT 20080530.094224/public/01 front.pdf.

26. Morah, E.M.I., Wilson, J. \& Tzempelikos, N. (2015). Moderation effects on the market orientation-performance connubial relationship: a developing world perspective. In: Academy of Marketing Conference, 09 July 2015, University of Limerick, Republic of Ireland.

27. Morah, E.M.I., Wilson, J. and Tzempelikos, N. (2015). Moderation effects on the market orientation-performance connubial relationship: a developing world perspective. In: Academy of Marketing Conference, 09 July 2015, University of Limerick, Republic of Ireland.

28. Narver, J.C. \& Slater, S.F. (1990). The effect of a market orientation on business profitability, Journal of Marketing, 54(4), pp. 20-35.

29. Narver, J.C. \& Slater, S.F. (1996). Competitive strategy in market-focused business, Journal of Market Focused Management, 1, pp. 159-174.

30. Narver, J.C. \& Slater, S.F. (1990). The effect of marketing orientation on business profitability, Journal of Marketing, $4(1)$, pp. 20-36.

31. Njeru, W. and Munyoki, M.J. (2014). Market orientation, external environment and performance of tour firms in Kenya, Journal of Business Administration and Management, 4(7), pp. 1515-1525.

32. Nwokah, N.G. (2008). Strategic market orientation and business performance: The study of food and beverages organizations in Nigeria, European Journal of Marketing, 3/4, pp. 279-286.

33. Oczkowski, E. \& Farrell, M.A. (1998). Discriminating between measurement scales using non-nested tests and two-stage least squares estimators: the case of market orientation, International Journal of Research in Marketing, 15(4), pp. 349-366.

34. Ong, W.J., Yeap, F.P. and Ismail, H. (2015). The Effects of Demographic Factors on Market Orientation, American Journal of Economics, 5(2), pp. 64-73.

35. Pongwiritthon, R. and Awirothananon, T. (2014). Customer Orientation and Firm Performance among Thai SMES, International Journal of Advanced Biomedical Engineering Research, 12(3), pp. 867-883.

36. Pulendran, S., Speed, R and Widing, R.E. (2000). The Antecedents and Consequences of Market Orientation in Australia, Australian Journal of Management, 25, pp. 119-143.

37. Reijonen, H., Laukkanen, T., Komppula, R. and Tuominen, S. (2012). Are Growing SMEs More Market-Oriented and Brand-Oriented? Journal of Small Business Management, 50(4), pp. 699-716.

38. Rose, G.M. and Shoham, A. (2002). Export Performance and Market Orientation: Establishing an Empirical Link, Journal of Business Research, 55, pp. 217-225.

39. Sargeant, A. \& Mohamad, M. (1999). Business Performance in the UK hotel sector-does it pay to be market oriented? The Service Industries Journal, 19(3), pp. 42-59.

40. Shergill, G.S. and Nargundkar, R. (2005). Market orientation, marketing innovation as performance drivers: extending the paradigm, Journal of Global Marketing, 19 (1), pp. 27-44.

41. Slater, S.F. \& Narver, J.C. (1994). Does Competitive Environment Moderates the Market-Orientation Performance Relationship? Journal of Marketing, 58(1), pp. 46-55.

42. Van Raaij, E.M. and Stoelhorst, J.W. (2008). The Implementation of Market Orientation, European Journal of Marketing, 42(11/12), pp. 1265-1293.

43. Verhees, F.J.H.M. and Meulenberg, M.T.G. (2004). Market orientation, innovativeness, product innovation and performance in small firms, Journal of Small Business Management, 42(2), pp. 134-154.

44. Vieira, A.V. (2010). Antecedents and Consequences of market orientation: a Brazilian meta-analysis and an international mega-analysis, Brazilian Administration Review, 7(1), pp. 40-58.

45. Watson, J. (2002). Comparing the performance of male- and female-controlled businesses: Retailing outputs to inputs, Entrepreneurship Theory and Practice, 26(3), pp. 91-100.

46. Wiklund, J. \& Shepherd, D.A. (2005). Entrepreneurial orientation and small business performance: a configurational approach, Journal of Business Venturing, 20, pp. 71-91.

47. Zairi, M. (2011). Process Innovation Management. New York: Taylor \& Francis. 